\title{
Recent Issues on Human Capital Formation and Development of the Nigerian Economy
}

\author{
Haruna Abdullahi ${ }^{1}$, Gylych Jelilov ${ }^{2, *}$, Selman Tetik ${ }^{3}$ \\ ${ }^{1}$ Macro Economic Analysis Department, Ministry of Budget and National Planning, Nigeria \\ ${ }^{2}$ Department of Economics, Faculty of Social Science, Nile University of Nigeria, Nigeria \\ ${ }^{3}$ Department of Business Administration, Faculty of Management, Nile University of Nigeria, Nigeria
}

Copyright $(\mathrm{O} 2018$ by authors, all rights reserved. Authors agree that this article remains permanently open access under the terms of the Creative Commons Attribution License 4.0 International License

\begin{abstract}
The role of human capital formation in economic growth and development has been highly underestimated in Nigeria. The study at this moment attempts to create an insight into the importance of human capital formation using real GDP per capita, government expenditure on health, government expenditure on education and primary school enrolment in the case of Nigeria. It used time series data from 1980 to 2017 and employed OLS regression technique, Johanssen cointegration and Granger causality test. The results from the various methods utilized affirmed the importance of human capital formation towards actualizing economic growth and development in Nigeria. The ordinary least square regression result showed a positive relationship between Government capital expenditure on health, Education and primary school enrolment. The Johanssen cointegration result showed cointegrating vectors in both the trace and maximum Eigenvalue test. The results from the Granger causality test indicated a bi-directional between primary school enrolment and Real GDP, a Uni-directional relationship between real GDP and government capital expenditure on health and education. The study strongly recommends a more budgetary capital allocation to health and education. The study went further to suggest strategies that would ensure the increase in primary school enrolment.
\end{abstract}

Keywords Human Capital, Development, Nigeria, Public Expenditure

JEL Code: O15, E24, E22, O10, 055.

\section{Introduction}

Human capital formation refers to a process that involves the employment of various strategies and policies with the sole aim of equipping the labor force of a country with requirements that will enhance the performance of affect productivity of labor positively.

Nigeria is a country with a population estimated at 180 million and a population growth rate of $2.3 \%$. Fortunately, the bulk of Nigeria's population are youths between ages 24 and 40 .

The opinion was that human capital talks about the human factor in the production process that entails the combination of intellectual and physical abilities of the labor force. Among factors of production, labor stands out as the only one that possesses the ability to evolve and acquire various skill sets over time that would enhance productivity [1].

Human capital refers to the talents and expertise of a labor force, while human capital formation is the practice of investing in skills, education and experience that are imperative to the actualization of sustainable economic growth and development of an economy.

Over the years, reasonable importance is attached to the accumulation of physical capital at the expense of human capital in Nigeria's pursuit for quick economic growth and development. Nonetheless, previous development strategies which failed to focus on the social or human aspects of growth development was futile towards attaining the desired pace of growth and development in the country.

Currently, Nigeria is facing various social vices associated with underdeveloped countries. With average life expectation measured at 41 years, high child mortality rate and more than $60 \%$ of its population living below poverty line, Nigeria are ranked 20th in Africa and 152nd in the world regarding Human Development Index. Nigeria as a country is currently directing efforts toward emerging among the most developed nations in the world shortly. However, this aspiration is destined to be a failed endeavor unless human capital formation tops the priority list. The human capital formation is the most crucial factor in actualizing fast economic growth and development 
because all advanced developed economies today have larger service sectors than agriculture and industry sectors. Many studies in recent times have classified human capital formation as crucial is behind the success of any service sector of any country.

Though there is a reasonable amount of publications on the importance of human capital formation on economic growth or development, none of the papers examined investigates the precise implication of human capital formation on both economic growth and development simultaneously in Nigeria over an extended period.

\section{Theoretical Framework}

For this study, we are going to use the augmented Solow human-capital-growth model. The theory is adopted due to its existence as advancement on the traditional Solow growth model. Robert Solow's initial growth model failed to dissect human capital. For that reason, the augmented Solow model was proposed by Mankiw, Romer and Weil in a Publication titled "A Contribution to the Empirics of Economic Growth" 1992. The rationale behind the inclusion of human capital in the model is the heterogeneity of labor in the production process of various economies depending on their quality of education and skills acquired. This adjustment expedites the applicability of the model and thus, the utilization of the model in the case of Nigeria. The underlying factor in the model is that investment in human capital will directly enhance output and further amplify growth.

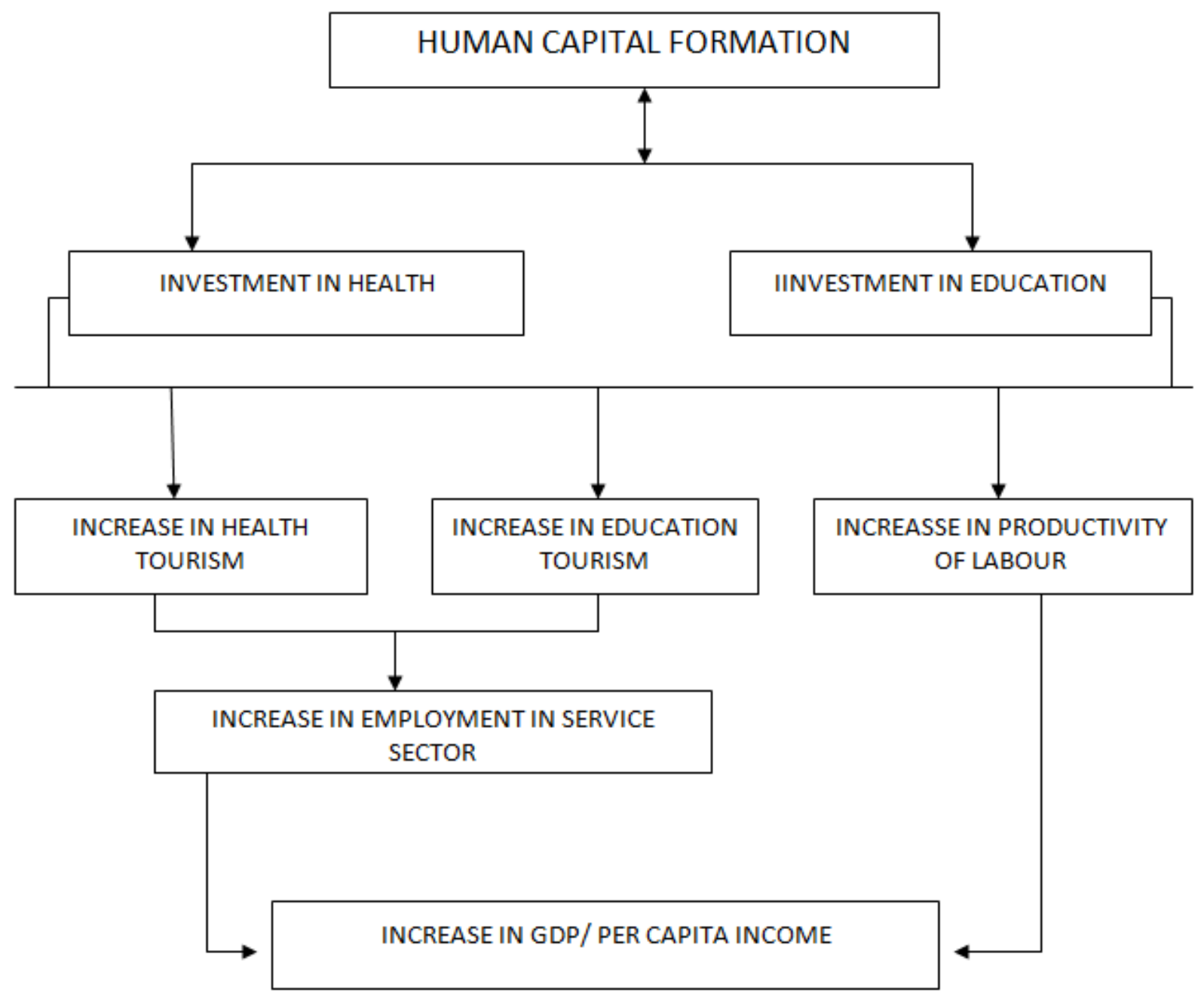

Figure 1. Conceptual Framework 


\section{Review of Empirical Literature}

Human capital formation and economic growth and development have been an issue of concern all over the world. Numerous studies in Nigeria and beyond have been carried out using various econometric techniques with the aim of observing the significance of human capital formation towards the actualization of economic growth and development. Most of the studies seem to have reached a unanimous conclusion that human capital formation stimulates economic growth and development. Some of the empirical literature reviewed is as follows;

- An analysis on the impact of human capital development on GDP was conducted for Nigeria. The study employed Johansen cointegration technique and vector error correction. The outcome of the Johanssen cointegration test indicated two cointegrating vectors in the trace test and one cointegrating equation in the Max. Eign value test. The cointegration technique further suggested that real capital expenditure on education, real recurrent expenditure on education and labor force has negative relationships with economic growth, while real capital stock and school enrollments are positively have positive relationships with economic growth. The test confirmed that real capital stock and school enrollments contribute to economic growth. The result of the vector error correction model proved that only labor force has immense effect on GDP within one year lag period in the short run. Government expenditure on education was also seen to have a negative implication on GDP. The paper recommended sufficient funding for human capital because it was considered a catalyst for economic growth (Sankay, Ismail., \& Shaari, 2010).

- Using time series data from 1970 and 2010, a study focused on Nigeria, used ADF unit root test, Vector Error Correction (VEC) and Pairwise Granger causality methodologies. The Augmented Dickey Fuller and Philip Perron test affirmed the stationarity of all the variables at first differencing, after which a Co-integration test was conducted. The outcome of the cointegration test proved the absence of co-integration between human capital formation and economic growth. The VAR model and pairwise causality test were then conducted, the findings showed a lack of causality between human capital formation and economic growth in Nigeria. However, the study still recommended the urgency to improve funding for the education/health sectors and creation of vocational institutions for skill acquisition (Amassoma \& Nwosa.P., 2011).

- Assessing the impact of government investment on human capital development and economic growth in Nigeria. The Ordinary least square regression found a positive relationship between economic growth and human capital development after using GDP to represent economic growth; public spending on education and health, and the enrolment pattern of tertiary, secondary and primary schools to represent human capital in the model. Consequently, the suggested that more measures of improving skills of people and explore various means of improving productivity of man power in the economy in order to achieve sustainable growth (Johnson, 2011).

- In the same vain, trying to examine the relationship between government investment and economic development, (Oluwatobi \& Ogunrinola, 2011) Suggested investment in health and education as sustainable ways of ensuring long-run growth and development of the Nigerian economy. The study made use of Cointegration and vector error correction model where a positive correlation was recorded using recurrent expenditure on health/education and economic growth while a negative observation made between capital spending in health/ education on economic growth.

- In efforts to measure the importance of education to the development of Nigeria, this study used school enrolment, government expenditure on health and physical capital formation to empirically examine how human capital affects the Nigerian economy. The study found primary school input, physical capital formation and health were found to have a positive impact on economic growth while Secondary school input and tertiary institutions had negative impact on economic growth (Adawo, 2011).

- Also in an attempt to evaluate the impact of human capital formation on economic growth in Nigeria, (Kanayo \& Ogujiuba, 2013) utilized the error correction model and concluded that investment in human capital at secondary level schools impacts positively on Nigeria's economic growth while capital expenditure on education was seen to have an insignificant impact on economic growth. The paper went further to recommend the restructuring of education at all levels to attain maximum quality and long-run positive impact.

- Similarly, (Victori \& Similola, 2015) launched an inquiry using time series data from 1982 to 2011 to analyze the role of human capital investment on economic growth in Nigeria. The result from the Johanssen cointegration test proves the existence of long-run relationship between Human capital investment and Real GDP while the result of the ordinary least square regression showed a negative relationship between primary school enrollment and government capital expenditure on education.

- In a comparative study between Nigeria and Turkey, OLS and Granger causality techniques were used concerning the endogenous growth Model, the 
results indicated that health is an essential determinant of growth in Turkey. However, no such relationship is established for Nigeria. Turkish higher human capital accumulation, therefore, appears to be the factor that causes growth differences in these countries (Eris, 2012).

- A research on Sudan by (Abdalla, Arabi, \& Sulaiman, 2013) was conformity to most studies in Nigeria after it identified a link between school enrolment, investment in health, education and general productivity. This conclusion is based on the results of three staged least squares technique.

- A research investigating the relationship between Capital Accumulation and Economic Growth in Nigeria embraced the Endogenous Growth Approach and found a positive correlation between the human capital formation and economic growth in Nigeria while utilizing the vector autoregressive model and autoregressive distributed lag model further confirmed a long-run relationship (Ogbuagu, Ewubare, \& Annuli, 2015).

- Similarly a research tested the significance of human capital formation in attaining economic growth as regards to Nigeria using Johanssen cointegration and OLS regression. The study used quarterly time series data from 1999-2012 and found that human capital development has a positive relationship with output level which was also inelastic thus concluding that human capital formation was imperative towards the actualization of steady economic prosperity (Eigbiremolen \& Anaduaka, 2014).

- Behroozina adopted the panel cointegration approach in a bid to estimate the importance of human capital on economic growth using 40 Asian countries. The study which covers 40 years exhibited evidence of strong causality between investment in education and economic growth in those countries. The research described investment in practice-oriented training as a means of creating jobs in the long run (Alizera Behrooznia, Shadizadeh, Laalbar, \& Karsalari, 2016).

- Also, in a research conducted to establish the link between Human Capital, Governance and Productivity in Asian Economies, findings of the ordinary least square regression technique confirmed a positive impact of human capital formation in 14 Asian countries. The study recommended more investment in primary education. (Mustafa \& Ghulam, 2012).

- However, Using education data from 55 countries in different regions from 1960 - 2009, another study created a panel data model to analyze the effect of education human capital on economic growth. The results showed that human education capital has a significant relationship with economic growth, a similar relationship recorded between human health capital, life expectancy and GDP per capita (Wang \& Liu, 2016).

- In the same vein, Mei Ling maintained that human formation crucial in attaining economic growth Using Henan. The conclusion is based on the results of ordinary least square regression technique with data ranging 1995-2012. The findings indicated that a percentage increase in human capital will lead to $0.28 \%$ increase in GDP while a percentage increase in labor capital will increase GDP by $0.44 \%$ and it went further to recommend an increase in expenditure in education in rural settlements (Mei-Ling, 2014).

- Also on a quest to determine the effect of government Human Capital investment on Economic Growth in Sub-Saharan Africa, another used 33 years data from Nigeria, South Africa and Ghana to analyze the government investment on health and education. The study utilized cointegration and vector correction model. The findings saw Health, and Education, to have significant positive effect on growth only in Nigeria, while literacy rate is insignificantly positive in all countries. The study concluded that sub-Saharan African countries should encourage school enrolment, increase budgetary allocation in health and education and prioritize skill development to achieve desired economic outcomes (Obialor \& C., 2017).

- Trying to measure the extent to which Human capital contributes to European economic growth, a similar research paper embraced a panel data approach using data from 1995 to 2009 and arrived the conclusion human capital and economic growth are positively related. The results from a panel of countries in Europe show that all the education indicators have significant and positive relationships with GDP per capita growth rates in the region. (Tiruneh \& Radvansky, 2011).

- Aiming to define the long-run effect of physical and human capital on GDP by using the panel data from 13 developed and 11 developing countries over 40 years a study used Gross fixed capital formation was in place of physical capital indicator while investment in education and life expectancy as a proxy for human capital indicators. Panel dynamic ordinary least square and fully modified Ordinary Least Square OLS panel Cointegrated regression models were utilized to check the overall impact and evidence of cointegration while comparing the significance of these physical and human capital variables according to these two different country groups. According to the results of panels dynamic ordinary least square and fully modified OLS models; the influence of human capital investment on GDP in the developed countries was seen to be 
higher than the impact in the developing nations. Also, the role of life expectancy at birth on GDP was found to be more significant in the developing economies (Akpolat \& Gökçe, 2014).

- Breton Made use of a dynamic Solow growth model, improved with human capital, labor-hours, and oil prices, to prove that Japan's growth in GDP/adult for the period 1969-2007 is a procedure of convergence to a steady-state world rate of $1 \% / y e a r$. The study found that each additional year of average schooling attainment during this period raised GDP/adult in Japan by 20 percent, which increased the annual growth rate by $1.8 \%$ in 1969 but by only $0.6 \%$ in 2007. The study made use of ordinary least squares regression (Breton \& R., 2013).

- A study conducted with the objective of bridging missing gap on the combined impact of human capital investment mechanisms on economic growth using Nigeria as a case study, (Osonba \& Tella, 2017) used secondary data from 1986-2016 on capital formation and real GDP to conduct a Fully Modified Ordinary Least Squares (FMOLS) technique. The findings disclosed that there was positive and significant relationship between the interactive effects of human capital components and growth in Nigeria. The study recommended more allocation to health and education sectors as well as training of personnel to improve service delivery.

Despite the disparity in econometric techniques, data, scope and areas of study, most of the publications reviewed above were of the opinion that human capital formation is a significant catalyst of sustainable growth and development in most economies.

The findings of these studies were further used to form the A-priori expectation where Human capital formation will be seen to have a long-run positive relationship with economic growth in Nigeria.

\section{Data and Methods}

The time-series data ranging from 1980 to 2017 will be sourced from Central Bank of Nigeria and National Bureau of Statistics. The first step will be to check the stationarity of the time series variables. Then variables are taken in their Natural Log form to correct possible anomalies in the data after which The Ordinary Least Square Regression technique is utilized to measure the effect of the independent variables on the dependent variable. Johanssen Cointegration is then used to enquire the existence of long-run relationship between the variables after which the Granger Causality test will be used to check the future direction of correlation between the dependent and the independent variables.

\section{Model Specification}

The model will be derived in line with the Augmented Solow Growth Model while referring [12]. The model will be derived in line with the Augmented Solow Growth Model while referring

$$
\gamma=A K^{\propto}(h L)^{\beta} \mu
$$

Where:

$\mathrm{Y}=$ Output level or GDP growth

$\mathrm{K}=$ Stock of physical capital

$\mathrm{h}=$ Level of Human Capital

$\mathrm{L}=$ Labor (Number of workers)

$\mathrm{A}=$ Level of Total Factor Productivity

$\alpha=$ Elasticity of capital input with respect to the output

$\beta=$ Elasticity of labor input with respect to output.

$\mu=$ Stochastic error term

To fit in this study, the model is as follows:

$$
\begin{aligned}
\log R G D P P C & =\propto+\log G C E X . E+\log G C E X . H \\
& +\log P S E+\mu
\end{aligned}
$$

Where

LogRGDPPC $=$ Real GDP per capita

LogGCEX.E $=$ Government capital expenditure on education

LogGCEX.H= Government capital expenditure on health

LogPSE $=$ Primary school enrolment

$\mu=$ Stochastic error term

Real GDP per capita is used as a proxy for both economic growth and development. Government capital expenditure on education, health and primary school enrolment was used as variables to reflect human capital formation efficiently.

\section{Presentation of Findings and Results}

Table 1. ADF unit root test results

\begin{tabular}{cccc}
\hline VARIABLES & $\begin{array}{c}\text { ADF -T } \\
\text { STATISTIC }\end{array}$ & $\begin{array}{c}\text { Critical } \\
\text { Value }\end{array}$ & Probability \\
\hline LogRGDPPC & -3.932045 & -12.4758 & 0.0054 \\
LogGEX.E & -3.010583 & -7.1023 & 0.0010 \\
LogGEX.H & -3.418616 & -9.7364 & 0.0208 \\
LogPSE & -4.561036 & -8.3749 & 0.0145 \\
\hline
\end{tabular}

In the table above the results shows that at the 5\% significance level the variables are stationary first difference. The test was conducted using trend and intercept at 12 lags. The results confirm the null hypothesis that the variables have a unit root and are summarized in the table where the $\mathrm{T}$-statistic values were greater than the critical values and the probabilities were all less than 0.05 thus making the results significant. This qualifies the test for ordinary least square regression, Johanssen 
cointegration and Granger causality test. Findings of the methods above are hereby in conformity with (Amassoma \& Nwosa.P., 2011).

Table 2. OLS Results

\begin{tabular}{|c|c|c|c|c|}
\hline & Coefficient & $\begin{array}{c}\text { Standard } \\
\text { Error }\end{array}$ & T-statistics & Probability \\
\hline C & 1.74463 & 2.5988 & 1.6390 & 0.000 \\
LGCEX.E & 0.47505 & 0.02166 & 7.1094 & 0.002 \\
LGCEX.H & 0.22811 & 0.03346 & 5.7553 & 0.004 \\
LPSE & 0.61992 & 0.01124 & 9.223 & 0.001 \\
$R^{2}$ & 0.9241 & & & \\
F-statistics & 75.9983 & & & \\
D.W & 0.8632 & & & \\
Statistics & & & & \\
\hline
\end{tabular}

Source: Author

\section{Summary}

- The coefficient of Government capital expenditure on education stood at 0.47 . It shows that a unit increase in Government capital expenditure on education would increase GDP per capita by $47 \%$ approximately.

- The coefficient of Government capital expenditure on health in the result is 0.22 . It shows that government capital expenditure on health is positively related to GDP per capita and a unit increase in it would increase the GDP by $22 \%$ approximately.
- The coefficient of Primary school enrolment is 0.61 . It means that a unit increase in primary school enrolment would increase GDP per capita by $61 \%$.

- The results above are in conformity with (Eigbiremolen \& Anaduaka, 2014) where variables of human capital formation were seen to have positive significant effect on economic growth but in total opposition with findings of (Victori \& Similola, 2015) and (Oluwatobi \& Ogunrinola, 2011) where variables of human capital formation were seen to have positive impact on economic growth.

The existence of a long run relationship between the independent variables and dependent variable is examined by using the cointegration test. (Sankay, Ismail., \& Shaari, 2010) opined that if the trace statistic and the Max-Eigen statistic are greater than the $5 \%$ critical values, the null hypothesis of no co-integration will be rejected in favor of the alternative hypothesis at that level.

In the result above, both the trace statistics and Max-Eigen statistics indicate three cointegrating equations at $5 \%$ significance level. It proves that there exists a long run relationship among the variables. The trace value shows probability levels of $0.0 \%, 2.0 \%$ and $2.04 \%$ which disagrees with the hypothesis that no cointegration exists among the variables. The Max-Eigen statistic results show that at 5\% significant level, there are probability values of $4.8 \%, 2.55 \%$, and $3.61 \%$ which also gives reason to accept the alternative of the null hypothesis. . The trace test and the Max-Eigen test show that there is co-integration among the variables thus implying a long run equilibrium relationship.

Table 3. Johanssen Cointegration

\begin{tabular}{|c|c|c|c|c|c|c|}
\hline $\begin{array}{c}\text { Hypothesized } \\
\text { No. of CE(s) }\end{array}$ & $\begin{array}{c}\text { Trace } \\
\text { Statistic }\end{array}$ & $\begin{array}{c}0.05 \text { Critical } \\
\text { value }\end{array}$ & Probability & $\begin{array}{c}\text { Max-Eigen } \\
\text { Statistic }\end{array}$ & $\begin{array}{c}0.05 \text { Critical } \\
\text { value }\end{array}$ & Probability \\
\hline None * & 65.45826 & 40.17493 & 0.0000 & 31.14398 & 24.15921 & 0.0048 \\
\hline At most $1 *$ & 34.31428 & 24.27596 & 0.0020 & 19.71114 & 17.79730 & 0.0255 \\
\hline At most 2 & 14.60314 & 12.32090 & 0.0204 & 12.02158 & 11.22480 & 0.0361 \\
\hline At most 3 & 2.581564 & 4.129906 & 0.1278 & 2.581564 & 4.129906 & 0.1278 \\
\hline
\end{tabular}

Source: Authors

Table 4. Granger Causality Test

\begin{tabular}{|c|c|c|}
\hline Null Hypothesis & F-Statistic & Probability \\
\hline GDPPC does not Granger Cause GCEX.E & $\begin{array}{c}0.01507 \\
1.32864\end{array}$ & $\begin{array}{c}0.0322 \\
0.00592\end{array}$ \\
\hline GCEX.E does not Granger Cause GDPPC & 0.09614 & 0.0489 \\
\hline GCEX.H does not Granger Cause GDPPC & 2.26556 & 0.0134 \\
\hline GDPPC does not Granger Cause GCE.H & 0.89169 & 0.0221 \\
\hline PSE does not Granger Cause GDPPC & 11.6149 & 0.3534 \\
\hline
\end{tabular}

Source: Author 
The granger causality test is used to examine the relationship between the variables. The findings from this test show the direction of relationship among the variables. The variables are tested at a $5 \%$ significance level.

- At 5\% significance level the first result shows a Bi-directional relationship between GDP per capita and Government capital expenditure on education at probability levels of $3.22 \%$ and $0.5 \%$. It means there's the long-run relationship between GDP per capita and Government capital expenditure on education.

- At 5\% significance level, the second result also shows a Bi-directional relationship between Government expenditure on health and GDP per capita at probability levels of $4.89 \%$ and $1.34 \%$. It means that the two variables affect each other.

- At 5\% significance level, the last result shows a Uni-directional relationship between Primary school enrolment and GDP per capita at probability levels of $2.1 \%$ and $35.34 \%$. The result gives reason to reject the hypothesis that Primary school enrolment does not Granger causes GDP per capita. It means that an increase in the GDP per capita would not have a positive impact on Primary school enrolment but an increase in Primary school enrolment would affect in the future.

\section{Conclusion \& Recommendations}

The results from all the econometric techniques we utilized for this research affirmed our a-priori expectations stated initially. The summary of the various models showed the positive long-run relationship between the variables. Furthermore, the results of the model that confirms the impact of human capital formation on economic growth are also in line the augmented Solow growth model chosen for this study. It emphasizes the heterogeneity of labor and identifies the human capital as the agent behind the difference in the productivity of labor. In summary, the results proved that human capital formation is decisive in the attaining higher output in a production function.

1. The Nigerian Government should make all primary schools: The econometric model used for this study has provided evidence that primary school enrolment is beneficial to towards the growth of the Nigerian economy. The best approach towards increasing primary school enrolment is by making tuition fee-free in all primary schools.

2. The government should make primary school compulsory: In another bid to facilitate primary school enrolment, the Nigerian government should pass a bill compelling all parents and guardians in the country to enrol their wards into primary school.

3. More budgetary allocation should be in health and Education sectors: In addition to the Abuja declaration 2001 that stipulates that at least $15 \%$ of every annual budget must be spent in the health sector, the Nigerian government must also implement policies that will ensure sufficient funding for research and the education sector.

4. To improve the total literacy rate and productivity in the economy, the Nigerian government should consider setting up vocational programs for skill acquisition that will capture disabled, uneducated and Inmates of a correctional facility. It will equip incarcerated individuals and the disabled to have skills for self-sustenance and also improve their economic value and raise aggregate productivity in the economy.

\section{REFERENCES}

[1] Human capital formation as a catalyst for National development: Nigeria in Perspective. Ejere, S.I. 2011, International business and Management, pp. 2-2.

[2] The impact of human capital development on the economic Growth of Nigeria. . Sankay, O.J., Ismail., R. and Shaari, A. H. 2010, Prosiding Perkem V, pp. 67-73.

[3] Investment in Human Capital and Economic Growth in Nigeria: A Causality Approach. Amassoma, D. and Nwosa.P. I. 2011, Canadian Social Science, pp. 114-120.

[4] Human Capital Development and Economic Growth in Nigeria. Johnson, A.O. 2011, European Journal of Business and Management, pp. 29-38.

[5] Government expenditure on human capital development: Implications for economic frowth in Nigeria. Stephen O. Oluwatobi, Oluranti. I. Ogunrinola. 2011, Journal of Sustainable Development, p. 3.

[6] Has education (human capital) contributed to the economic growth of Nigeria? Adawo, M.A. 2011, Journal of Economics and International Finance, pp. 46-58.

[7] The Impact of Human Capital Formation on economic growth in Nigeria. Kanayo, Ogujiuba. 2013, J Economics, pp. 121-132.

[8] Human capital investment and economic growth in Nigeria. Victoria, Similola. 2015, African Research Review Ethiopia, pp. 30-46.

[9] A HUMAN CAPITAL AND ECONOMIC GROWTH: COMPARATIVE ANALYSIS OF THE IMPACT OF KNOWLEDGE AND. Eris, Kehinde OGUNLEYE and Bilge. 2012, The Journal of Knowledge Economy \& Knowledge Management, pp. 109-126.

[10] The impacto of human capital growth: empirical evidence from sudan. Abdalla, Mohammed Arabi and Sulaiman. 2013, research in word economy, pp. 43-53.

[11] Capital accumulation and economic growth in Nigeria. Ogbuagu, Dennis Ewubare and Annuli. 2015, IOSR Journal of Economics and Finance, pp. 49-64.

[12] Human capital development and economic growth: the 
Nigerian experience. Eigbremolen, Anaduaka. 2014, international journal of academic research in business and social sciences, pp. 25-35.

[13] Human capitan and economic growth in Asian countries. Alizera Behrooznia, Reza Shadizadeh, Ali Laalbar, Abbas Karsalari. 2016, International journal of academic research in accounting, finance and management sciences, pp. 1-6.

[14] Human capital, governance and prooductivity in asian economies. Mustafa, Ghulam. 2012, Job market paper, pp. $1-31$.

[15] Education, Human Capital and Economic Growth: Empirical Research on 55 countries and regions. Ying Wang, Sasha Liu. 2016, scientific research publishing, pp. 1-9.

[16] Empirical analysis on the relationship between human capital investment and economic growth in rural areas:
Based on data of Henan. Mei-Ling, shi. 2014, Journal of chemical and pharmaceutical research, pp. 378-382.

[17] Effect of government human capital investment on economic growth in sub-saharan Africa. Obialor, Michael C. 2017, IDEAS, pp. 1-19.

[18] The contribution of Human capital to Europe Economic growth: Aempirical exploration from a panel data. Menbere Tiruneh, Marek Radvansky. Ponta Delada, Azores Research gate, 2011. Ecomod. pp. 1-11.

[19] The Long-Term Impact of Human Capital Investment on GDP: A Panel Cointegrated Regression Analysis. Akpolat, Ahmet Gökçe. 2014, Economics Research International, pp. $1-10$.

[20] Human Capital and Growth in Japan: Converging to the Steady State in a 1\% World. Breton, Theodore R. 2013, SRRN, pp. 1-5. 